\title{
Vertical transmission of Bartonella schoenbuchensis in Lipoptena cervi
}

Arnout de Bruin ${ }^{1 *}$, Arieke Docters van Leeuwen ${ }^{1}$, Setareh Jahfari ${ }^{1}$, Willem Takken², Mihály Földvári ${ }^{3}$, László Dremmel ${ }^{4}$, Hein Sprong ${ }^{1,2}$ and Gábor Földvári ${ }^{*}$

\begin{abstract}
Background: Lipoptena cervi (Diptera: Hippoboscidae) is a hematophagous ectoparasite of cervids, which is considered to transmit pathogens between animals and occasionally to humans. The principal life stage that is able to parasitize new hosts is a winged ked that just emerged from a pupa. To facilitate efficient transmission of pathogens between hosts, vertical transmission from female deer keds to their offspring is necessary. We investigated vertical transmission of several vector-borne pathogens associated with cervids.
\end{abstract}

Methods: Deer keds from several locations in Hungary were collected between 2009 and 2012. All life stages were represented: winged free-ranging adults, wingless adults collected from Capreolus capreolus and Cervus elaphus, developing larvae dissected from gravid females, and fully developed pupae. The presence of zoonotic pathogens was determined using qPCR or conventional PCR assays performed on DNA lysates. From the PCR-positive lysates, a gene fragment was amplified and sequenced for confirmation of pathogen presence, and/or pathogen species identification.

Results: DNA of Bartonella schoenbuchensis was found in wingless males (2\%) and females (2\%) obtained from Cervus elaphus, dissected developing larvae (71\%), and free-ranging winged males (2\%) and females (11\%). DNA of Anaplasma phagocytophilum and Rickettsia species was present in L. cervi adults, but not in immature stages. DNA of Candidatus Neoehrlichia mikurensis was absent in any of the life stages of L. cervi.

Conclusions: $B$. schoenbuchensis is transmitted from wingless adult females to developing larvae, making it very likely that $L$. cervi is a vector for B. schoenbuchensis. Lipoptena cervi is probably not a vector for A. phagocytophilum, Rickettsia species, and Candidatus N. mikurensis.

Keywords: Lipoptena cervi, Deer ked, Pathogen, Vector, Anaplasma, Bartonella, Rickettsia, Ixodes ricinus

\section{Background}

Lipoptena cervi (deer ked) is an obligate hematophagous ectoparasite of cervids and domesticated animals [1,2], which occasionally bites humans [3]. This species has a Palearctic distribution and belongs to a highly specialized family of flies (Diptera: Brachycera), called louse flies (Hippoboscidae) [4,5]. Within the family Hippoboscidae, a few species are known to transmit zoonotic

\footnotetext{
* Correspondence: arnout.de.bruin@rivm.nl; foldvarigabor@gmx.de ${ }^{1}$ Centre for Zoonoses \& Environmental Microbiology, Centre for Infectious Disease Control, National Institute for Public Health and the Environment, Bilthoven, the Netherlands

${ }^{5}$ Department of Parasitology and Zoology, Faculty of Veterinary Science, Szentlstván University, Budapest, Hungary

Full list of author information is available at the end of the article
}

pathogens or protozoan parasites to wildlife, or domesticated animals [6-8].

In general, $L$. cervi is considered a mere nuisance for animals only [9], and clinical symptoms after they bite humans are not very severe $[10,11]$. However, $L$. cervi is also considered a potential vector for a number of zoonotic pathogens, such as Bartonella, Anaplasma, and Rickettsia species [12-14]. Lipoptena cervi shows a number of interesting life history traits, in which vertical transmission of pathogens from females to offspring seems to be essential to facilitate efficient transmission between vertebrate hosts. The life cycle of $L$. cervi starts (arbitrarily) with free-ranging winged adult deer keds that search for suitable (cervid) hosts. After landing on a host, they crawl into the fur, shed their wings and 
thereby become permanently associated with that host. The wingless deer keds frequently take blood meals from that host, which is soon followed by mating. After that, a larva will develop (one at a time) that is retained by the female until the third instar. This third instar larva is deposited on the cervid fur as a white prepupa, which immediately starts to pupate. The fully developed and darkened pupa drops to the ground and remains there until August-September, after which a new generation of winged adult keds can emerge $[2,15]$.

When in search for a host, winged adult $L$. cervi are attracted to large moving dark colored objects [3], fly short distances only, and often attack unsuitable hosts (e.g. humans) [15]. The loss of its wings, invoked by crawling through the fur of a host [15], makes any subsequent host switch of $L$. cervi difficult or impossible [16]. However, it was suggested that wingless adults from another hippoboscid species, Neotropical deer ked L. mazamae, can be transmitted mechanically from female white-tailed deer to their offspring [17]. Nevertheless, vertical transmission of pathogens from female deer keds to their offspring is most likely a prerequisite for efficient vector potential.

A number of studies show that various zoonotic pathogens are present in a number of the mentioned life stages of L. cervi. Bartonella schoenbuchensis, causing deer ked dermatitis in humans, was isolated from the gut of wingless adult L. cervi [10]. Although detection of $B$. schoenbuchensis in wingless adult deer keds was confirmed by others as well $[13,18]$, DNA of this particular pathogen has not been detected in immature L. cervi life stages. However, DNA of Bartonella species in general, including potential endosymbionts, was detected in $L$. cervi wingless adults [12,18], fully developed pupae $[8,12]$, and free-ranging winged deer ked adults [8]. These findings at least support vector potential of $L$. cervi for (zoonotic) Bartonella species.

In addition to Bartonella, Anaplasma species may be transmitted by $L$. cervi as well. Anaplasma ovis, which causes anaplasmosis primarily in sheep, was detected in a single free-ranging winged adult deer ked. However, none of the additional adult wingless deer keds collected from roe and red deer tested positive for Anaplasma spp. [14]. In contrast to $A$. ovis, $A$. phagocytophilum can cause anaplasmosis both in sheep and cattle, and a zoonotic disease referred to as granulocytic anaplasmosis in humans $[19,20]$. This pathogen was detected in $L$. cervi wingless adults, collected from cervids that tested negative for this pathogen, but not in free-ranging winged adult deer keds [21]. In another study, wingless adult deer keds, obtained from culled roe deer, were found positive for A. phagocytophilum as well [22]. Additional molecular typing revealed that A. phagocytophilum ecotype II was found especially in roe deer, Ixodes ricinus ticks, and deer keds.
Finally, vector potential of $L$. cervi for Rickettsia species was studied as well. Rickettsiae are non-motile, Gram-negative, highly pleomorphic bacteria, which can be transmitted by competent arthropod vectors, such as ticks, lice, and fleas, and can cause a large number of zoonotic diseases in humans [23]. Rickettsia helvetica and other unidentified Rickettsia species were detected in pools of wingless adult $L$. cervi, collected from roe deer and red deer, but not in winged free-ranging adult deer keds [14]. Although pathogenic potential of $R$. helvetica is still unclear, this pathogen has been associated with acute perimyocarditis [24], an unexplained febrile illness [25], and recently also with meningitis [26].

In this study, the vector potential of $L$. cervi was further explored for four zoonotic pathogens: Candidatus Neoehrlichia mikurensis, A. phagocytophilum, Bartonella spp., and Rickettsia spp. We tested winged freeranging adults, wingless adults collected from roe deer and red deer, developing larvae dissected from females, and pupae collected from the fur of cervids for the presence of these zoonotic pathogens.

\section{Methods}

Collection of Lipoptena cervi and DNA extraction procedures Between 2009 and 2012, 345 deer keds and fully developed pupae were collected from different locations in Hungary. A total of 248 wingless adult deer keds (males and females), and three developed pupae were collected from one male and ten female Cervus elaphus hosts, and two Capreolus capreolus hosts (one male and one female). In addition, 94 free-ranging winged adult deer keds (52 males and 42 females) were collected during the same time period from various locations in Hungary. No ethical approval is required for the experimental methods used in this study.

In the laboratory, seven wingless adult female deer keds were dissected, and developing larvae were harvested. For all samples, DNA was extracted first by alkaline lysis as described earlier [27]. For a number of samples that showed coloration or a turbid DNA suspension after alkaline lysis, a Qiagen DNA extraction procedure [28] was performed to further purify DNA from co-extracted substances that may inhibit downstream (q)PCR reactions.

\section{PCR assays and sequencing procedures}

Extracted DNA was tested for the presence of four zoonotic pathogens: Candidatus N. mikurensis, A. phagocytophilum, Bartonella spp., and Rickettsia spp. For detection of A. phagocytophilum and Candidatus N. mikurensis DNA, a single multiplex qPCR assay was used, which targets specific regions of genes $m s p 2$ (Major Surface Protein 2) for A. phagocytophilum, and groEL (heat shock protein) for Candidatus N. mikurensis. This was followed by conventional PCR and sequencing part of 
the groEL gene for samples positive for A. phagocytophilum. Detection of $A$. phagocytophilum and Candidatus N. mikurensis DNA by qPCR, and confirmation by sequencing of positive samples were performed as described earlier [22,28]. For detection of Bartonella spp. a conventional PCR assay was used, which targets a part of the citrate synthase gene $(g l t A)$. This was followed by sequencing of positive samples for species identification. Both conventional PCR and sequencing procedures were performed, as described earlier [29].

For detection of Rickettsia species, we used a multiplex qPCR assay, in which two different regions of the gltA gene are targeted. We designed primers and probes to amplify a region of the gltA gene, specific for $R$. helvetica (Table 1). This assay was combined with primers and probes designed by Stenos et al., which amplify a different region of the gltA gene for the detection of Rickettsia species in general [30]. All qPCR runs were carried out in a final volume of $20 \mu \mathrm{l}$ containing IQ Multiplex Powermix (Bio-Rad), and $400 \mathrm{nM}$ of primers and hydrolysis probes. Conditions for PCR amplification were the following: $95^{\circ} \mathrm{C}$ for $5 \mathrm{~min}, 60$ thermocycles at $95^{\circ} \mathrm{C}$ for $5 \mathrm{~s}$, and $60^{\circ} \mathrm{C}$ for $35 \mathrm{~s}$, followed by a final incubation step at $37^{\circ} \mathrm{C}$ for $20 \mathrm{~s}$. PCR assays were carried out on a LightCycler 480 instrument (Roche Diagnostics Nederland B.V, Almere, the Netherlands), and analysis was performed on the instrument's software (release 1.5.1.62). Quantification cycle (Cq) values were calculated using the second derivative method. For samples positive for Rickettsia DNA in qPCR, conventional PCR was performed on a gltA region, using forward and reverse primers CS490 and Rp1258n as described by Roux et al. [31]. PCR amplification was carried out using the HotStarTaq master mix (Qiagen, Westburg, Germany), and $400 \mathrm{nM}$ primers in a total reaction volume of $25 \mu \mathrm{l}$. Thermocycling conditions were the following: $95^{\circ} \mathrm{C}$ for $15 \mathrm{~min}, 40$ cycles at $94^{\circ} \mathrm{C}$ for $30 \mathrm{~s}, 54^{\circ} \mathrm{C}$ for $30 \mathrm{~s}$, and $72^{\circ} \mathrm{C}$ for $55 \mathrm{~s}$, followed by a final step at $72^{\circ} \mathrm{C}$ for $7 \mathrm{~min}$. We included three $\mu \mathrm{l}$ of DNA template. Conventional PCRs were carried out in a $\mathrm{P} \times 2$ thermal cycler (Thermo Electron Corporation, Breda, the Netherlands). PCR products were visualized on a $2 \%$ agarose gel, and sequenced by BaseClear according to the company's protocol. BLAST analysis was performed to confirm Rickettsia species identification.

Using Fisher's exact test on $2 \times 2$ contingency tables, we tested if there was a significant difference between numbers of male and female deer keds positive to Bartonella and A. phagocytophilum.

\section{Results and discussion}

Bartonella DNA was detected in all life stages of L. cervi, except the three fully developed pupae (Table 2). We detected Bartonella DNA in 182 of ked samples, including wingless adult males and females collected from both red deer and roe deer, free ranging winged males and females, and larvae harvested from adult females. Sequencing part of the gltA gene revealed the presence of Bartonella schoenbuchensis DNA in free-ranging winged adults (one male and five females), wingless adults (two males and three females), and five harvested developing larvae (Table 2). These findings indicate that Bartonella is transmitted vertically from wingless females to larvae that will develop into pupae. However, Bartonella DNA was not detected in the three pupae collected from red or roe deer, probably due to the small sample size. Although we were not able to detect Bartonella in fully developed pupae, it is very likely that $L$. cervi is a vector for this pathogen. Other studies showed that Bartonella DNA was present in various $L$. cervi life stages as well $[8,10,12,13,18]$. In addition, it was reported that another hippoboscid species (Melophagus ovinus) is able to transmit Bartonella vertically from females to their offspring [13].

Anaplasma phagocytophilum DNA was detected in 123 (35\%) of deer ked samples, 119 were wingless adults collected from red deer, two were free-ranging winged adults, and two remnants of female adult deer keds after dissection and removal of developing larvae (Table 2). We were able to confirm the presence of $A$. phagocytophilum by conventional PCR and sequencing in five wingless adult females and six wingless adult males. We found no A. phagocytophilum DNA in adult deer keds collected from roe deer, pupae collected from both red deer and roe deer, or in larvae harvested from adult females. Since the majority of A. phagocytophilum-positive deer ked samples were wingless adults, and we found no Anaplasma DNA in developing larvae and fully developed pupae, vertical transmission of this pathogen from females to offspring is not very likely. In addition, the number of positive winged adults is also quite limited and presence of $A$. phagocytophilum DNA could not be confirmed by sequencing. The finding of Anaplasmapositive winged $L$. cervi adults in combination with the

Table 1 Newly developed primers and probe for Rickettsia helvetica targeting a region of the gltA gene

\begin{tabular}{llll}
\hline Primers \& probe & Oligo name & Primer and probe sequences (5'- > 3') & Product length \\
\hline forward primer & Rick_HelvgltA_F2 & ATGATCCGTTTAGGTTAATAGGCTTCGGTC & 123 bp \\
reverse primer & Rick_HelvgltA_R2 & TTGTAAGAGCGGATTGTTTTCTAGCTGTC \\
Probe (Atto425) & Rick_HelvgltA_pr3 & ATTO425-CGATC + C + ACG + TG + CCGCAGT-BHQ1 (+ = LNA) & \\
\hline
\end{tabular}

LNA = Locked Nucleic Acid, indicated by symbol ' + '. 
Table 2 Detection of vector-borne pathogens in various life stages of $L$. cervi

\begin{tabular}{llllllll}
\hline Description & L. cervi life stage & Samples & A. phagocytophilum & Rickettsia spp. & R. helvetica & Bartonella spp. & B. schoenbuchensis \\
\hline Red deer & Wingless male & 97 & $49(51 \%)$ & $6(6 \%)$ & $3(3 \%)$ & $56(58 \%)$ & $2(2 \%)$ \\
& Wingless female & 125 & $70(56 \%)$ & $18(14 \%)$ & $7(6 \%)$ & $95(76 \%)$ & $3(2 \%)$ \\
& Developed pupae & 2 & - & - & - & - & - \\
\multirow{5}{*}{ Roe deer } & Wingless male & 7 & - & - & - & $2(29 \%)$ & - \\
& Wingless female & 13 & - & - & - & $2(15 \%)$ & - \\
& Developed pupae & 1 & - & - & - & - & - \\
\multirow{5}{*}{ Free-ranging } & Winged male & 52 & $1(2 \%)$ & $2(4 \%)$ & - & $6(12 \%)$ & $1(2 \%)$ \\
& Winged female & 42 & $1(2 \%)$ & $3(7 \%)$ & $1(2 \%)$ & $9(21 \%)$ & $5(12 \%)$ \\
Dissection & Developing larvae & 7 & - & - & - & $6(86 \%)$ & $5(71 \%)$ \\
& Remnants from females & 6 & $2(33 \%)$ & - & - & $6(100 \%)$ & - \\
Total & & 352 & 123 & 29 & 11 & 182 & 16 \\
\hline
\end{tabular}

absence of positive larvae and pupae is rather puzzling. It may be possible that these winged $L$. cervi have taken a blood meal from another (unsuitable) host, retained their wings somehow, and were able to search for another more suitable host. Other studies reported the presence of $A$. phagocytophilum in only wingless adults as well $[21,22]$, and together with our results, this indicates that $L$. cervi is probably not involved in the transmission of A. phagocytophilum.

For Rickettsia spp., 29 deer ked samples were found positive for a gltA sequence detected using primers and probes designed by Stenos et al. [30]. In addition, 11 deer ked samples were positive for Rickettsia helvetica, using primers and probes designed specifically for a gltA region of this species. Four deer ked samples showed positive results based on both gltA regions. Rickettsia DNA was detected in wingless $L$. cervi males and females, originating from red deer, and in free-ranging winged deer keds. However, qPCR assay results indicated very low levels of Rickettsia DNA present within the samples. Therefore, we were not able to confirm Rickettsia DNA presence by subsequent conventional PCR and sequencing. As for A phagocytophilum, dissected developing larvae and fully developed pupae showed no positive results for Rickettsia DNA, which indicates that vertical transmission of Rickettsia species by $L$. cervi females is not very likely. The absence of vertical transmission and the presence of Rickettsia species in winged and wingless deer keds only indicate that $L$. cervi is probably not involved in the transmission of rickettsiae.

We detected no Candidatus N. mikurensis DNA in any of the deer ked life stages collected. According to literature, Candidatus N. mikurensis is primarily transmitted by ticks [28,32], and we found no reports in which this pathogen was transmitted by other vectors. In addition, Candidatus N. mikurensis can be found in several rodent species, which may act as reservoir hosts
[28,33-35]. However, we found no reports of this pathogen present in deer. Red deer and roe deer are incompetent hosts for Borrelia burgdorferi s.l. genospecies $[36,37]$, and are even known to be able to reduce Borrelia infections in I. ricinus ticks [38,39]. Therefore, it may also be possible that the same deer species are incompetent reservoir hosts for Candidatus N. mikurensis as well. Together with our findings, this indicates that although $L$. cervi and ticks (I. ricinus) can share a common host (cervids), L. cervi is probably not involved in the transmission of Candidatus N. mikurensis.

On red deer, we observed larger numbers of positive wingless females in comparison to positive wingless males for all three pathogenic genera. For Bartonella and Rickettsia species, the difference between wingless positive females and males was significant $(p=0.005$ and $p=0.038$, respectively). Free-ranging females also had a higher prevalence for these two bacteria, however not significantly due to low sample size. This is an unexpected difference, since it is reported that when unfed, both male and female deer keds have the same weight, and when blood-fed, males are heavier than females [40]. Therefore, the significantly more infected females cannot be the result of a larger blood meal compared to males. One explanation is that Rickettsia and Bartonella species (zoonotic or endosymbionts) are able to colonize and/or survive in females more efficiently than in males. Since vertical transmission of pathogens in $L$. cervi is necessary for efficient transmission between vertebrate hosts, strong selection toward infection of female deer keds can be expected. However, a (molecular) mechanism for this is still unknown.

Another possibility is the involvement of endosymbionts in this phenomenon. In common with other insects, in which all the life stages are dependent solely on blood as the nutrient source, hippoboscids have symbionts. These symbionts are housed in a mycetome on the intestine and are transferred to offspring accompanied to 
nutrients provided by the mother for her intra-uterine larva [41]. Many maternally inherited endosymbionts manipulate their host's reproduction in various ways to enhance their own fitness. One such mechanism is male killing, in which sons of infected mothers are killed by the endosymbiont during development as described for Wolbachia in another dipteran, Drosophila innubila [42]. Nycterophiliine bat flies (Diptera, Streblidae), belonging to a related parasitic family to louse flies, were recently shown to have Wolbachia endosymbionts [43] but, unfortunately, hippoboscid flies were not examined for these, only for other endosymbionts [44]. Either in co-occurrence with endosymbionts or functioning as endosymbionts themselves, Bartonella and/or Rickettsia spp. infection in female deer ked might lead to more female offspring compared to uninfected females, possibly resulting in the observed asymmetry in the female: male ratio of infected individuals.

Finally, we were not able to test blood or tissue samples of roe or red deer, from which the wingless adult deer keds were collected for presence of pathogens. However, cervids are known reservoir hosts for at least a number of zoonotic pathogens we investigated [45-49].

\section{Conclusions}

Detection of pathogens in wingless females, developing larvae, and fully developed pupae indicates vertical transmission from female $L$. cervi to their offspring. The only deer ked life stage that is able to search actively for new hosts is a winged adult following eclosion from a pupa. Therefore, vertical transmission and detection of pathogens in emerged winged adults is essential to show vector potential of $L$. cervi.

Anaplasma phagocytophilum, or Rickettsia species were not present in harvested developing larvae or fully developed pupae, and only a limited number of winged male and female deer keds were found positive for these pathogens. Therefore, $L$. cervi is probably not a vector for A. phagocytophilum, and Rickettsia species.

Bartonella schoenbuchensis is vertically transmitted from wingless females to developing larvae. It is very likely that $L$. cervi is a vector for Bartonella, including the zoonotic pathogen $B$. schoenbuchensis, because we identified this zoonotic pathogen in dissected developing larvae and free ranging winged $L$. cervi males and females.

\section{Competing interests}

The authors declare that they have no competing interests.

\section{Authors' contributions}

$A d B$ and GF analyzed data, performed statistical analyses, and wrote the final manuscript. MF, LD, and GF collected deer ked samples, and GF performed dissection of deer keds. ADVL and SJ performed lab tests and analyzed laboratory results. WT and HS designed and supervised parts of the study. All authors read and approved the final manuscript.

\section{Acknowledgements}

We would like to thank Gábor Majoros, Sándor Szekeres, Krisztina Rigó, Éva Gabriella Földvári and Barna Bende Földvári for their help in sample collection. This study was financially supported by the Dutch Food and Consumer Product Safety Authority (NWWA) and by the Ministry of Health, Welfare and Sport (MWS). GF was supported by the János Bolyai Research Scholarship of the Hungarian Academy of Sciences and an NKB and Research Faculty grants from the Faculty of Veterinary Science, Szentlstván University. This work was done under the frame of EurNegVec Cost Action TD1303.

\section{Author details}

${ }^{1}$ Centre for Zoonoses \& Environmental Microbiology, Centre for Infectious Disease Control, National Institute for Public Health and the Environment, Bilthoven, the Netherlands. ${ }^{2}$ Laboratory of Entomology, Wageningen University, Wageningen, the Netherlands. ${ }^{3}$ MTA-DE 'Lendulet' Behavioural Ecology Research Group, Department of Evolutionary Zoology, University of Debrecen, Debrecen, Hungary. ${ }^{4}$ Institute of Wildlife Management and Vertebrate Zoology, Faculty of Forestry, University of West Hungary, Sopron, Hungary. ${ }^{5}$ Department of Parasitology and Zoology, Faculty of Veterinary Science, Szentlstván University, Budapest, Hungary.

Received: 11 December 2014 Accepted: 24 February 2015

Published online: 21 March 2015

\section{References}

1. Kynkaanniemi SM, Kettu M, Kortet R, Harkonen L, Kaitala A, Paakkonen T, et al. Acute impacts of the deer ked (Lipoptena cervi) infestation on reindeer (Rangifer tarandus tarandus) behaviour. Parasitol Res. 2014;113(4):1489-97.

2. Madslien $K$, Ytrehus B, Viljugrein H, Solberg EJ, Braten KR, Mysterud A. Factors affecting deer ked (Lipoptena cervi) prevalence and infestation intensity in moose (Alces alces) in Norway. Parasit Vectors. 2012;5:251.

3. Kortet R, Harkonen L, Hokkanen P, Harkonen S, Kaitala A, Kaunisto S, et al. Experiments on the ectoparasitic deer ked that often attacks humans; preferences for body parts, colour and temperature. Bull Ent Res. 2010;100(3):279-85.

4. Bequaert JC. A Monograph of the Melophaginae Or Ked-Flies of Sheep, Goats, Deer, and Antelopes (Diptera, Hippoboscidae): Brooklyn Entomological Society. 1942.

5. Maa TC. A synopsis of the Lipopteninae (Diptera: Hippoboscidae). J Med Entomol. 1965;2(3):233-48.

6. Baker J. A review of the role played by the Hippoboscidae (Diptera) as vectors of endoparasites. J Parasitol . 1967:412-8

7. Kennedy PG. The continuing problem of human African trypanosomiasis (sleeping sickness). An Neur. 2008;64(2):116-26.

8. Korhonen EM, Perez Vera C, Pulliainen AT, Sironen T, Aaltonen K, Kortet R, et al. Molecular detection of Bartonella spp. in deer ked pupae, adult keds and moose blood in Finland. Epidemiol Infect. 2014;143(3):1-8.

9. Paakkonen T, Mustonen AM, Kakela R, Kiljander T, Kynkaanniemi SM, Laaksonen S, et al. Experimental infection of the deer ked (Lipoptena cervi) has no negative effects on the physiology of the captive reindeer (Rangifer tarandus tarandus). Vet Parasitol. 2011;179(1-3):180-8.

10. Dehio C, Sauder U, Hiestand R. Isolation of Bartonella schoenbuchensis from Lipoptena cervi, a blood-sucking arthropod causing deer ked dermatitis. J Clin Microbiol. 2004;42(11):5320-3.

11. Rantanen T, Reunala T, Vuojolahti P, Hackman W. Persistent pruritic papules from deer ked bites. Acta Derm Venereol. 1982;62(4):307-11.

12. Duodu S, Madslien K, Hjelm E, Molin Y, Paziewska-Harris A, Harris PD, et al. Bartonella infections in deer keds (Lipoptena cervi) and moose (Alces alces) in Norway. Appl Environ Microbiol. 2013;79(1):322-7.

13. Halos L, Jamal T, Maillard R, Girard B, Guillot J, Chomel B, et al. Role of Hippoboscidae flies as potential vectors of Bartonella spp. infecting wild and domestic ruminants. Appl Environ Microbiol. 2004;70(10):6302-5.

14. Hornok S, de la Fuente J, Biro N, de Fernandez Mera IG, Meli ML, Elek V, et al. First molecular evidence of Anaplasma ovis and Rickettsia spp. in keds (Diptera: Hippoboscidae) of sheep and wild ruminants. Vec Zoon Dis. 2011;11(10):1319-21.

15. Haarløv N. Life cycle and distribution pattern of Lipoptena cervi (L.)(Dipt., Hippobosc.) on Danish deer. Oikos. 1964;15(1):93-129.

16. Hackman W, Rantanen T, Vuojolahti P. Immigration of Lipoptena cervi (Diptera, Hippoboscidae) in Finland, with notes on its biology and medical significance. Not Ent. 1983;63:53-9. 
17. Samuel W, Trainer D. Lipoptena mazamae Rondani, 1878 (Diptera: Hippoboscidae) on white-tailed deer in southern Texas. J Med Entomol. 1972;9(1):104-6.

18. Tijsse-Klasen E, Fonville M, Gassner F, Nijhof AM, Hovius EK, Jongejan F, et al. Absence of zoonotic Bartonella species in questing ticks: first detection of Bartonella clarridgeiae and Rickettsia felis in cat fleas in the Netherlands. Parasit Vectors. 2011;4:61.

19. Stuen S, Granquist EG, Silaghi C. Anaplasma phagocytophilum-a widespread multi-host pathogen with highly adaptive strategies. Front Cell Inf Microbiol. 2013;3:31.

20. Jin H, Wei F, Liu Q, Qian J. Epidemiology and control of human granulocytic anaplasmosis: a systematic review. Vec Zoon Dis. 2012;12(4):269-74.

21. Víchová B, Majláthová V, Nováková M, Majláth I, Čurlík J, Bona M, et al. PCR detection of re-emerging tick-borne pathogen, Anaplasma phagocytophilum, in deer ked (Lipoptena cervi) a blood-sucking ectoparasite of cervids. Biologia. 2011;66(6):1082-6.

22. Jahfari $S$, Coipan EC, Fonville $M$, van Leeuwen AD, Hengeveld P, Heylen D, et al. Circulation of four Anaplasma phagocytophilum ecotypes in Europe. Parasit Vectors. 2014;7:365.

23. Merhej V, Angelakis E, Socolovschi C, Raoult D. Genotyping, evolution and epidemiological findings of Rickettsia species. Infection, genetics and evolution. J Mol Epidemiol Evol Gen Infect Dis. 2014;25:122-37.

24. Nilsson K, Lindquist O, Pahlson C. Association of Rickettsia helvetica with chronic perimyocarditis in sudden cardiac death. Lancet. 1999;354 (9185):1169-73.

25. Nilsson K. Septicaemia with Rickettsia helvetica in a patient with acute febrile illness, rash and myasthenia. J Infect. 2009;58(1):79-82.

26. Nilsson K, Elfving K, Pahlson C. Rickettsia helvetica in patient with meningitis, Sweden. Emerg Infect Dis. 2010;16(3):490-2.

27. Wielinga PR, Gaasenbeek C, Fonville M, de Boer A, de Vries A, Dimmers W, et al. Longitudinal analysis of tick densities and Borrelia, Anaplasma, and Ehrlichia infections of Ixodes ricinus ticks in different habitat areas in The Netherlands. Appl Environ Microbiol. 2006;72(12):7594-601.

28. Jahfari S, Fonville M, Hengeveld P, Reusken C, Scholte EJ, Takken W, et al. Prevalence of Neoehrlichia mikurensis in ticks and rodents from North-west Europe. Parasit Vectors. 2012:5:74.

29. De Sousa R, Edouard-Fournier P, Santos-Silva M, Amaro F, Bacellar F, Raoult D. Molecular detection of Rickettsia felis, Rickettsia typhi and two genotypes closely related to Bartonella elizabethae. Am J Trop Med Hyg. 2006;75(4):727-31.

30. Stenos J, Graves SR, Unsworth NB. A highly sensitive and specific real-time PCR assay for the detection of spotted fever and typhus group Rickettsiae. Am J Trop Med Hyg. 2005;73(6):1083-5.

31. Roux V, Rydkina E, Eremeeva M, Raoult D. Citrate synthase gene comparison, a new tool for phylogenetic analysis, and its application for the rickettsiae. Int J Syst Bacteriol. 1997;47(2):252-61.

32. Maurer FP, Keller PM, Beuret C, Joha C, Achermann Y, Gubler J, et al. Close geographic association of human neoehrlichiosis and tick populations carrying "Candidatus Neoehrlichia mikurensis" in eastern Switzerland. J Clin Microbiol. 2013;51(1):169-76.

33. Andersson M, Raberg L. Wild rodents and novel human pathogen candidatus Neoehrlichia mikurensis, Southern Sweden. Emerg Infect Dis. 2011;17(9):1716-8.

34. Vayssier-Taussat M, Le Rhun D, Buffet JP, Maaoui N, Galan M, Guivier E, et al. Candidatus Neoehrlichia mikurensis in bank voles, France. Emerg Infect Dis. 2012;18(12):2063-5.

35. Szekeres S, Claudia Coipan E, Rigo K, Majoros G, Jahfari S, Sprong H, et al. Candidatus Neoehrlichia mikurensis and Anaplasma phagocytophilum in natural rodent and tick communities in Southern Hungary. Ticks Tickborne Dis. 2014;6(2):111-6.

36. Jaenson TG, Tälleklint L. Incompetence of roe deer as reservoirs of the Lyme borreliosis spirochete. J Med Entomol. 1992;29(5):813-7.

37. Telford 3rd SR, Wormser GP. Bartonella spp. transmission by ticks not established. Emerg Infect Dis. 2010;16(3):379-84.

38. Rosef O, Paulauskas A, Radzijevskaja J. Prevalence of Borrelia burgdorferi sensu lato and Anaplasma phagocytophilum in questing Ixodes ricinus ticks in relation to the density of wild cervids. Acta Vet Scand. 2009;51:47.

39. Pacilly F, Benning M, Jacobs F, Leidekker J, Sprong H, Van Wieren S, et al. Blood feeding on large grazers affects the transmission of Borrelia burgdorferi sensu lato by Ixodes ricinus. Ticks Tickborne Dis. 2014;5(6):810-7.
40. Paakkonen T, Mustonen AM, Roininen H, Niemela P, Ruusila V, Nieminen P. Parasitism of the deer ked, Lipoptena cervi, on the moose, Alces alces, in eastern Finland. Med Vet Ent. 2010;24(4):411-7.

41. Lehane MJ. The biology of blood-sucking in insects: Cambridge University Press. 2005.

42. Unckless RL, Jaenike J. Maintenance of a male-killing Wolbachia in Drosophila innubila by male-killing dependent and male-killing independent mechanisms. Evolution; Int J Org Evol. 2012;66(3):678-89.

43. Morse SF, Dick CW, Patterson BD, Dittmar K. Some like it hot: evolution and ecology of novel endosymbionts in bat flies of cave-roosting bats (hippoboscoidea, nycterophiliinae). Appl Environ Microbiol. 2012;78(24):8639-49.

44. Duron O, Schneppat UE, Berthomieu A, Goodman SM, Droz B, Paupy C, et al. Origin, acquisition and diversification of heritable bacterial endosymbionts in louse flies and bat flies. Mol Ecol. 2014;23(8):2105-17.

45. Dehio C, Lanz C, Pohl R, Behrens P, Bermond D, Piemont Y, et al. Bartonella schoenbuchii sp. nov., isolated from the blood of wild roe deer. Int JSyst Eevol Microbiol. 2001;51(Pt 4):1557-65

46. Skotarczak B, Adamska M. Detection of Bartonella DNA in roe deer (Capreolus capreolus) and in ticks removed from deer. Eur J Wildlife Res. 2005;51(4):287-90.

47. Rar V, Golovljova I. Anaplasma, Ehrlichia, and "Candidatus Neoehrlichia" bacteria: pathogenicity, biodiversity, and molecular genetic characteristics, a review. Infect Genet Evol J Mol Epidemiol Evol Gen Inf Dis. 2011;11(8):1842-61.

48. Malmsten J, Widen DG, Rydevik G, Yon L, Hutchings MR, Thulin CG, et al. Temporal and spatial variation in Anaplasma phagocytophilum infection in Swedish moose (Alces alces). Epidemiol Infect. 2014;142(6):1205-13.

49. Overzier E, Pfister K, Herb I, Mahling M, Bock Jr G, Silaghi C. Detection of tick-borne pathogens in roe deer (Capreolus capreolus), in questing ticks (Ixodes ricinus), and in ticks infesting roe deer in southern Germany. Ticks Tickborne Dis. 2013;4(4):320-8.

\section{Submit your next manuscript to BioMed Central and take full advantage of:}

- Convenient online submission

- Thorough peer review

- No space constraints or color figure charges

- Immediate publication on acceptance

- Inclusion in PubMed, CAS, Scopus and Google Scholar

- Research which is freely available for redistribution

Submit your manuscript at www.biomedcentral.com/submit
C BioMed Central 